\begin{tabular}{|c|c|c|}
\hline Beitr. Ent. & Keltern & ISSN 0005-805X \\
\hline $\mathbf{5 8}(2008) 1$ & S. $205-210$ & 15.07 .2008 \\
\hline
\end{tabular}

\title{
Dancing behavior of Cosmopterix victor STRINGER, a species new to the fauna of China
}

\section{(Lepidoptera: Cosmopterigidae)}

With 3 figures

\author{
Steven R. Davis and Sergey Yu. Sinev
}

\begin{abstract}
Summary
A bamboo-feeding species Cosmopterix victor STRINGER, 1930 is mentioned from mainland Asia for the first time, with a description and illustration of its very striking dancing behavior. This behavior is regarded as a special adaptation providing the aggregation of adults on the host plants for mating and subsequent oviposition.
\end{abstract}

Keywords

Microlepidoptera, Zhejiang Province, Cosmopterigidae, Cosmopterix victor, dancing behavior.

\section{Zusammenfassung}

Zum ersten Mal wird ein Fund der Bambus fressenden Art Cosmopterix victor STRINGER, 1930 vom asiatischen Festland gemeldet. Weiterhin wird das sehr auffällige Tanzverhalten dieser Art beschrieben und abgebildet. Dabei handelt es sich um eine spezielle Anpassung, um für eine Ansammlung der adulten Schmetterlinge auf der Wirtspflanze zur Paarung und anschließenden Eiablage zu sorgen.

\section{Introduction}

The genus Cosmopterix is an easily recognized group, composed of approximately 185 species worldwide, and distinct from other Cosmopterigidae by its characteristic wing pattern (SINEV 2002; Koster and Sinev 2003; Kuroko and Liu 2005). Although many species are nearly identical in wing pattern, their genital morphology bears striking differences (HodGes 1962; Sinev 1985, 1988, 1997). The East Asian fauna of Cosmopterix has been reviewed mainly by Sinev and Kuroko, and the Chinese fauna is in great need of further systematic study.

In the summer of 2006 the first author spent approximately 30 minutes on Tian Mu mountain (Zhejiang Province, China) observing several specimens of Cosmopterix dancing on the leaves of unknown species of bamboo (Poaceae: Bambuseae).

This paper represents the identification of the moths and the first detailed documentation of dancing in the family Cosmopterigidae, including a depiction and explanation of the manner in which the dance is performed. 


\section{Materials and Methods}

Specimens of Cosmopterix were observed dancing on foliage along the primary hiking trail ascending to the peak of Tian Mu Shan, Zhejiang Province, China. Video footage of two specimens was taken with a Nikon Coolpix 5400 digital camera. Dissections were made using a Zeiss Stemi SV11 stereomicroscope.

\section{Results}

The determination of the material made by the second author revealed that all specimens collected belong to Cosmopterix victor STRINGER, 1930, one of the largest species of the genus originally described and previously known only from Japan.

\section{Cosmopterix victor STRINGER, 1930}

Cosmopteryx victor Stringer, Annls \& Mag. nat. Hist. (10) 6: 416 (1930).

Cosmopterix victor: Kuroкo, Kontyû 25 (1): 30, pl. 2, figs. 1 and 2 (o genitalia), pl. 3, fig. 3 (o genitalia) (1957); Issıkı, Icones Heterocerorum Japonicorum: 39, pl. 7, fig. 159 (moth) (1957); Кuroko, in Issiki, Early Stages of Japanese Moths in Color: 106, pl. 51, fig. 203 (moth, mine, and larva) (1969); Kuroko, in Inoue et al., Moths of Japan 1: 270; 2: pl. 11, fig. 14 (moth) (1982); Sinev, Entomol. Obozr. 76 (4): 829, fig. 24 (o genitalia), fig. 61 ( + genitalia) (1997).

Material examined: China: $20^{\star}$, Zhejiang Province: Tian Mu Shan, 30 June 2006, 1176 m, $30^{\circ} 20.634^{\prime} \mathrm{N}, 119^{\circ} 26.401^{\prime} \mathrm{E}, \mathrm{S}$. DAvis (coll. IZCAS); 1 ㅇ, Zhejiang Province: 'Ost Tien-mushan, Prov. Chekiang, 27.5.1931, H.Höne’ (coll. ZMFK, Bonn). Japan: $10^{\star}, 1$ ㅇ, Kyushu, Hikosan (Buzen), 15.vi.1955, H.Kuroko (coll. ZIAN, St.Petersburg).

\section{Distribution:}

Japan (Honshu, Shikoku, Kyushu) and eastern China (Zhejiang). New to China.

\section{Biology:}

Larvae mine leaves of Sasa japonica Makino, S. purpurascens OHWI, Phyllostachys bambusoides Sieb. et Zucc., and Arundinaria pygmaea Mitford (Poaceae: Bambuseae) (Kuroko 1957).

\section{Dancing behavior (Figs 1-3)}

Movements of the moth were never linear and consisted mainly of turns in which the caudal end of the adult would swing around more rapidly than the anterior end (Figs 1,3), demonstrating a motion much like that of the windshield wiper on an automobile. The antennae were held at an approximate $30^{\circ}$ angle from the lateral. In between these swinging motions were variable periods of spinning (Figs 1,2), in which two general types of rotation movements were observed. One type of spinning, referred to here as type 1 spinning, involved the moth positioning its head at one spot while the remainder of its body rotated around this central axis in a clockwise or counterclockwise direction. The second type of spinning, type 2 spinning, was very similar to type 1 , only the anterior end moved more and would not rotate around a single, fixed point. Type 2 spinning often immediately followed type 1 but did not always occur in this sequence. The number of 
rotations varied tremendously, with as few as 2 to as many as 18 rotations in one direction. Movements were never restricted to any given areas of the leaf, but were sometimes slightly more concentrated in some areas, with a few locations being visited more than once where spinning previously occurred. The total duration of the dance was not witnessed, nor was the beginning or end, however dancing that was observed lasted for over 3 minutes and ended only as a result of the specimens being collected.

\section{Discussion:}

The dancing behavior observed in C. victor is not characteristic of this species nor of Cosmopterix, but rather usual for many cosmopterigid genera, i.e. Labdia Walk., Vulcaniella RiedL, Ressia Sin., etc. (Sinev, 1993). In this family, many species are active before sunset, when they often dance on the leaves of shrubs and grasses making very peculiar circular passes. The similar styles of motions have been occasionally observed in several Gelechiidae (Beltheca), Elachistidae, Tineidae (Dryadaula), and Oecophoridae (Robinson 1988; Powell 1999; KaWahara and Adamski 2006; KUROKо pers. comm.; Nishida pers. comm.). Other types of dancing have been described in Brenthia (Choreutidae), which articulates its fore and hind wings as a mating display (AIELLO and BeCKer 2004) and in Nemophora (Incurvariidae), which performs another type of mating display (Oord 1981).

The reasons and implications for this dancing behavior were only shortly discussed by the authors. As noted for Beltheca oni by KaWAHARA and AdAmski (2006), this behavior could be involved in searching for drops of water on the leaf's surface, in which once the moth happens upon a drop of water, it inserts its haustellum into the droplet and consumes it while rotating. This situation is a possible explanation, although it was unclear whether water was present on the leaf or not due to the small scale of the situation.

However, foraging alone does not seem to be an adequate explanation for the complex movements involved in this dance. It is natural for an insect to make a random search path while foraging, but the swinging motions made during the random forward movements of Cosmopterix seem extraneous for foraging behavior. Besides that, the observed type 2 spinning does not appear to be relevant to drinking from drops of water as the type 1 spinning could explain. So, the question remains why such elaborate, exaggerative, seemingly aimless movements are performed by these moths.

It is much more likely that this dance is courtship related (SINEv, 1993, 1994). One can explain it as a kind of pre-mating behavior promoting the aggregation of individuals in the proper places. "The demonstration of presence" by peculiar movements on the leaves' surface combined with very bright coloration (contrasting black-and-white with shiny metallic stripes in Cosmopterix) evidently facilitates the meeting of different sexes as in the swarms of dipterans, hymenopterans and some lepidopterans (i.e. Adelidae). It is also very important that the dance of cosmopterigids takes places preferably on their host plants. The second author had an opportunity to observe this behavior for Cosmopterix zieglerella (HüBNER, [1810]) on Humulus lupulus L. (Canabaceae) in Ukraine, for C. pulchrimella CHAmbers, 1875 on Parietaria officinalis L. (Urticaceae) in Transcaucasia, for C.phyladelphella Sinev, 1985 on Philadelphus schrenkii Rupr. et Maxim. (Hydrangeaceae) and C. schmidiella Frey, 1856 on Maackia amurensis Rupr. et Maxim. (Fabaceae) in Primorye Territory (Russian Far East), etc. In some cases, the number of dancing specimens, both males and females, on a single plant attained several tens and even hundreds (for C. pulchrimella). After copulation, the female usually does not abandon the territory of a group of host plants and continues dancing on the leaves, only now searching for a suitable place for oviposition. It is usually a spinning of type 2 , when the female, testing the leaf surface by the tip of the ovipositor, lays eggs singularly on the under surface of the leaf along its main veins. 
The above described dancing behavior of Cosmopterix, as well as of other Lepidoptera, can be a special adaptation of monophagous and strictly oligophagous forms providing the aggregation of adults on the host plants for mating and subsequent oviposition. It allows uniting two different life activities, the searching for a sexual partner and the searching for appropriate host plant, which leads to the economy of energy and to the success of reproduction.

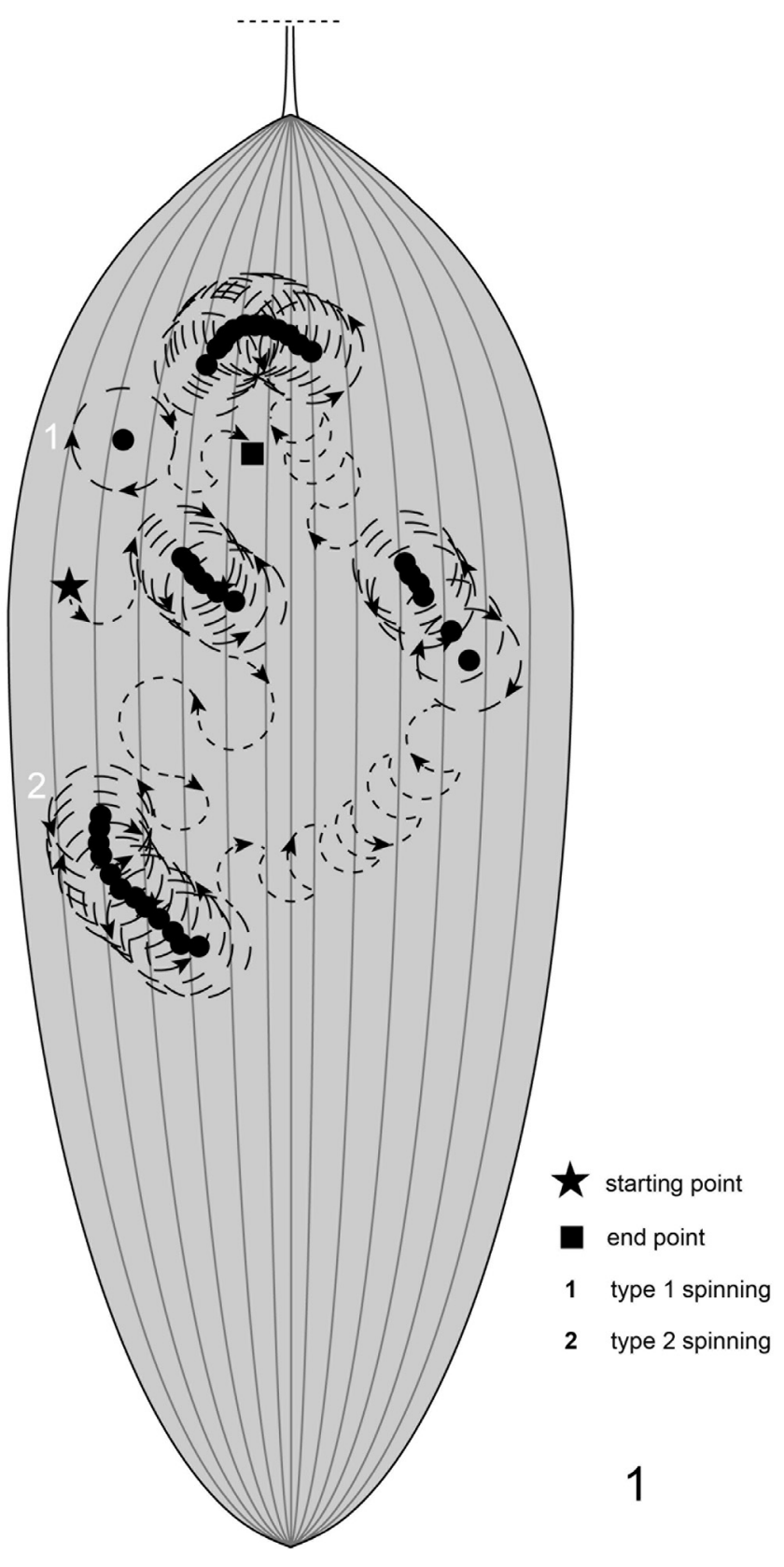

Fig. 1: Diagram of dance path on a leaf. Figure represents only a fragment of the entire dance. 

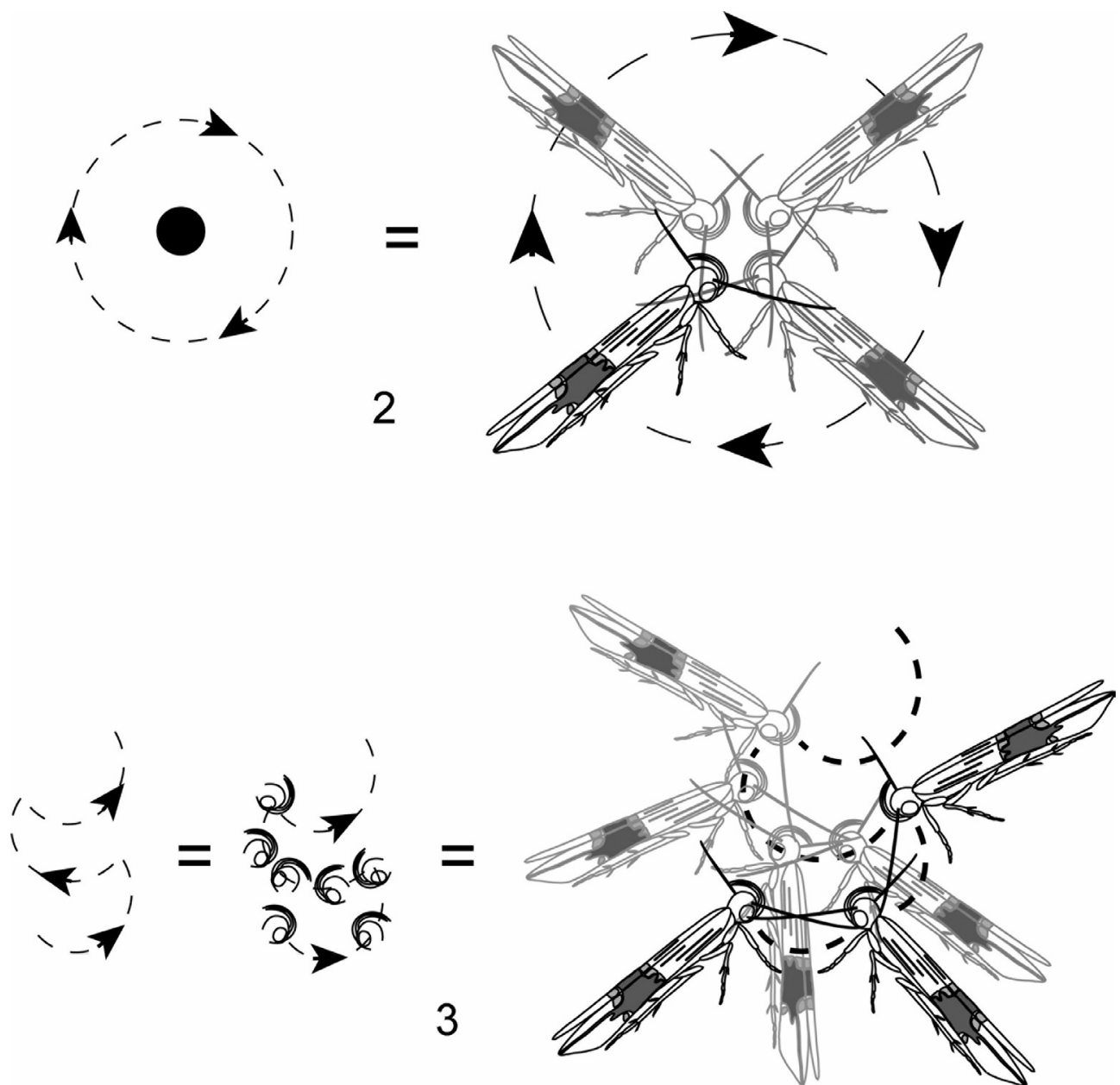

Figs 2-3: Depiction of body orientation during dance. 2, body orientation during spinning; 3, body orientation during swinging motion.

\section{Acknowledgements}

We would like to thank Mr. Guoqing Mai (IOZ, CAS, Beijing, China) for taking photos of the specimens, and Ms. Junhao Huang (IOZ, CAS, Beijing, China) for helping in curatorial matters involving the specimens. Much appreciation also goes to Dr. Michael S. Engel for offering valuable editorial comments, and Dr. Hiroshi Kuroko and Mr. Kenji Nishida for their comments regarding lepidopteran dancing. Support for the first author's travel to China was provided by NSF's EAPSI program in 2006.

\section{References}

Aiello, A. \& Becker, V. 2004: Display of the "peacock moth": Brenthia spp. (Choreutidae: Brenthiinae). - Journal of the Lepidopterists' Society 58 (1): 55-58.

Hodges, R. W. 1962: A revision of the Cosmopterigidae of America north of Mexico, with description of the Momphidae and Walshiidae (Lepidoptera: Gelechioidea). - Entomologica americana (N. S.) 42:1-171. 
Issiki, S. 1957: Icones Heterocerorum Japonicorum in Coloribus Naturalibus. - Osaka: Hoikusha. $\mathrm{xix}+318 \mathrm{p}$.

Kawahara, A. Y. \& Adamski, D. 2006: Taxonomic and behavioral studies of a new dancing Beltheca Busck (Lepidoptera: Gelechiidae) from Costa Rica. - Proceedings of the Entomological Society of Washington 108 (2): 253-260.

Koster, J. C. \& Sinev, S. Yu. 2003: Momphidae, Batrachedridae, Stathmopodidae, Agonoxenidae, Cosmopterigidae, Chrysopeleiidae. - In: Huemer, P.; Karsholt, O. \& Lyneborg, L. (eds): Microlepidoptera of Europe 5: 1-387.

Kuroko, H. 1957: Descriptions of Cosmopterix victor Stringer and its allied new species (Lepidoptera, Cosmopterigidae). - Kontyû 25: 30-32.

Киroко, H. 1969: Cosmopterigidae. - In: Issıкі, S.: Early Stages of Japanese Moths in Color: 105-106, pl. 51, fig. 203.

Kuroko, H. 1982: Cosmopterigidae. - In: Inoue, H.; Sugi, S.; Kuroko, H.; Moriuti, S. \& Kawabe, A.: Moths of Japan 1: 266-272; 2: pl. 11, 274-276.

Kunoko, H. \& Liu, Y. 2005: A study of Chinese Cosmopterix HüBner (Lepidoptera: Cosmopterigidae), with descriptions of new species. - Transactions of the Lepidopterists' Society of Japan 56 (2): 131-144.

Oord, W. 1981: Baltsviucht van Nemophora degeerella (Linnaeus) (Lep., Incurvariidae). - Entomologische Berichten 41 (5): 80.

Powell, J. A. 1999: The Hawaiian 'dancing moth', Dryadaula terpsichorella, has colonized coastal southern California (Lepidoptera: Tineidae). - Pan-Pacific Entomologist 75 (4): 221-223.

Robinson, G. S. 1988: The systematic position of Thermocrates epischista Meyrick (Lepidoptera: Tineidae) and the biology of the Dryadaulinae. - Nota Lepidopterologica 11 (1): 70-79.

Sinev, S. Yu. 1985: Новые виды рода Cosmopterix Нв. (Lepidoptera, Cosmopterigidae) с Аальнего Востока CCCP [New species of the genus Cosmopterix Нв. (Lepidoptera, Cosmopterigidae) from the Far East of the USSR]. - Trudy Zoologicheskogo Instituta 143: 73-94.

Sinev, S. Yu. 1988: Новые данные по фауне узкокрылых молей рода Cosmopterix (Lepidoptera, Cosmopterigidae) Палеарктики [New data on the Palaearctic fauna of narrow-winged moths of the genus Cosmopterix (Lepidoptera, Cosmopterigidae)]. - Zoologicheskii Zhurnal 67 (5): 705-712.

Sinev, S. YU. 1993: К биологии некоторых видов узкокрылых молей подсемейства Cosmopteriginae (Lepidoptera, Cosmopterigidae) [On the biology of a few narrow-winged moths from subfamily Cosmopteriginae (Lepidoptera, Cosmopterigidae)]. - Trudy Zoologicheskogo Instituta 193: 73-83.

Sinev, S. Yu. 1994: Fam. Cosmopterigidae. - In: Kuznetzov, V. I. (ed): Insects and mites - pests of agricultural plants 3 (1): 285-289.

Sinev, S. YU. 1997: Обзор узкокрылых молей рода Cosmopterix Нв. (Lepidoptera, Cosmopterigidae) Палеарктики [A review of cosmopterigid moths of the genus Cosmopterix Нв. (Lepidoptera, Cosmopterigidae) of the Palearctic Region]. - Entomologicheskoe Obozrenie 76: 813-829.

Sinev, S. Yu. 2002: World catalogue of cosmopterigid moths (Lepidoptera: Cosmopterigidae). - Trudy Zoologicheskogo Instituta 293: 1-182.

Authors' addresses:

Steven R. Davis

Division of Entomology

Natural History Museum, and

Dep. of Ecology \& Evolutionary Biol.

1501 Crestline Drive - Suite \#140

University of Kansas

Lawrence, Kansas 66049-2811, USA

steved@ku.edu
Subject editor:

Sergey Yu. Sinev

Laboratory of Insects Taxonomy

Zoological Institute of the

Russian Academy of Sciences

Universitetskaya nab. 1

199034 St.Petersburg

Russia

sinev@zin.ru 